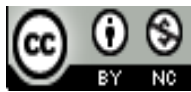 \\ Journal Terapan Manajemen dan Bisnis is licensed under \\ A Creative Commons Attribution-Non_Commercial 4.0 International License
}

\title{
Management of Drought Disaster in Indonesia
}

\section{Andi Mursidi ${ }^{1)}$, Deffi Ayu Puspito Sari ${ }^{2)}$}

\author{
'STKIP Singkawang, Singkawang, West Kalimantan, Indonesia \\ email: andimursidi@hotmail.com \\ ${ }^{2}$ Universitas Bakrie, Jakarta, South Jakarta, Indonesia \\ email: deffi.sari@bakrie.ac.id
}

\begin{abstract}
The drought disaster in Indonesia has occurred since 1811. Indonesia with tropical climate is highly sensitive to the climate anomaly El-Nino Southern Oscillation (ENSO) which is a source of drought. In addition to El Nino, the drought in Indonesia is also influenced by positive Indian Ocean Dipole (IOD) which constitute a regional climate phenomenon in Indian Ocean. The drought has widespread, complex impacts which lasts for a long time after the drought itself ends. This widespread impact lasting for so long is caused by the fact that water is a basic need and vital for every living creature, irreplaceable by any other resources. The impacts in agriculture sector include limited irrigation water, reduced planting areas, decreased land productivity, declined crops production, and less farmer's income, and from social perspective, the drought disaster may promote division and conflict which expand to include the conflict between water users and even between (local) governments. This paper summarizes efforts in managing drought disaster in Indonesia from the context of disaster management cycle.
\end{abstract}

Keywords: Drought Disaster, El-Nino, Water Crisis, Harvest Failure

\section{A. Introduction}

Seventy five percent of the world's population lives in areas affected at least once by earthquake, tropical cyclone, or drought between 1980 and 2000 (Hualou, 2011). Indonesia is the world's largest archipelagic country consisting of 17,508 islands and located in between Asia - Australia continents and Pacific - Indian Oceans. Situated along the equator line, the diverse and complex topography, and its wide sea surface distribution have led Indonesia to have high climate variability, both based on time and place. An example of this variability can be found in the rainfall. The high climate variability causes wet and dry extremes. When it is wet extreme, the potential for flood and landslide to occur increases. On the other hand, when it is dry extreme, the potential for prolonged dry season to occur is relatively high.

Disaster is a term that can be defined in different ways, depending on whether the spectrum is broad or narrow. Disasters have a detrimental impact, threatening the safety of human life, disrupt the community and affect national stability (Mamnunia, Sari, \& Heridadi, 2017). Organizations and agencies define it according to the context. For the Red Cross, a disaster is an occurrence such as hurricane, tornado, storm, flood, high water, wind driven water, tidal wave, earth quake, drought, blizzard, pestilence, famine, fire, explosion, volcanic eruption, terrorist attack, building collapse, transportation wreck or any other situation that causes human sufferings or creates human needs that the victims cannot alleviate without assistance (Red Cross) (Nithya, Rahul, \& Sneha, 2016). Disaster caused by flood, droughts, 
tidal wave, and earth tremor are generally considered by natural disaster (Dandagi, Moreshwar, \& Raddi, 2013). Disasters are global phenomena that are of major concern in all countries on the globe. Reports revealed that the frequency of major disasters and the quantities of losses/destruction resulted from it is increasing beyond expectation (Wand, Ayuba, \& Asika, 2015). The drought disaster in Indonesia, according to National Agency for Disaster Management's (BNPB) record, has occurred since the last two centuries, from 1811 until 2011 to be precise. Scarcity of water resources is influenced by the geography, for example in Tlogowaru, Malang and Gunung Kidul area in Yogyakarta (Tamim Syaifullah \& Manzilati, 2015) and (Puspitosari \& Afriono, 2017). Drought is the third major disaster after flood and fire. It means, special attention should be paid to respond to the drought occuring in many places in Indonesia.

Indonesia is located in a part of the world with tropical monsoon climate which is highly sensitive to the climate anomaly El-Nino Southern Oscillation (ENSO) that prolonged dry season in Indonesia, resulting in changes in cropping pattern and farm economy (Deffi Ayu Puspito Sari, 2010). Prolonged dry season also increase the prevalence of land and forest fire. Eight areas in Indonesia that are susceptible to drought as a result of land fire and dry season namely; Riau, Jambi, South Sumatera, North Sumatera, East Kalimantan, Central Kalimantan, South Kalimantan, and Kalimantan Barat.The regions severely affected by drought are East Nusa Tenggara, Sulawesi, and Java. Drought is a serious problem in Indonesia. Drought brings impact on agriculture, national economy, natural resources and the environment (Lotfi, Nahavandian, \& Mohseninia, 2016), drought limit the access to save and palatable water supply that impact in overall human capability and affecting the most in people under poverty (Deffi Ayu Puspito Sari, n.d.), (Deffi Ayu Puspito Sari, 2012) and (Deffi Ayu Puspito Sari \& Kawashima, 2016). During periods of drought (which can last as long as eight months), pastoralists' livelihoods become particularly precarious, and incidences of conflict over scarce water sources and pastures are more common (MacEwen, Choudhuri, \& Bird, 2011). Its cause is the decreased rainfall during a prolonged period, which is a result of the interaction between the atmosphere and the sea, and the irregular sea surface temperature which happens in Indonesia and its surrounding area, which are the phenomena of El Nino, positive IOD (Indian Ocean Dipole), and monsoon cycle.The drought in Indonesia, according to (Irawan, 2006), is generally related to climate anomaly event such as El Nino and positive IOD since out of 43 drought events between 1884 and 1998, only 6 events have nothidng to do with the El Nino phenomenon occuring in Pacific Ocean.

According to (Field, van der Werf, \& Shen, 2009), (D'Arrigo \& Smerdon, 2008) and (Toggweiler \& Key, 2003), the drought in Indonesia is also influenced by the positive IOD which is a regional climate phenomenon in Indian Ocean. Drought can result in widespread, complex impacts which last for a long time after the drought itself ends. The widespread, long-lasting impacts are due to the fact that water constitutes a basic and vital need for living creatures, irreplaceable by any other resources. The impacts in agriculture sector are limited irrigation water, reduced planting areas, decreased land productivity, declined crops production, and less farmer's income. And from social perspective, the drought disaster can also lead to division and conflict which may expand to include conflicts between water users and (local) governments.

\section{B. Classification of Droughts}

Drought is classified based on its causes; both natural causes and human intervention.

1. Natural Causes 
a. Meteorological Drought; it has something to do with rainfall rate below normal within a season. The meteorological drought measurement is the first indication that drought exists.

b. Hydrological Drought; it has something to do with lack of surface water and ground water supplies. This drought is measured based on the surface elevation of river, reservoir, and lake water, as well as ground water surface elevation. There is a grace period from the rain decrease until the decrease in surface elevation of river, reservoir, and lake water, as well as ground water surface elevation.Hydrological droughtis not an initial indication that drought exists.

c. Agricultural Drought; it has something to do with less soil moisture (water content in soil), so that it fails to fulfil certain plant's needs during certain period in a wide area. This agricultural droughtoccurs after meteorological drought symptoms.

d. Socio-Economic Drought; it has something to do with drought which influences people's socio-economic life, such as: damaged plants, farms, fisheries, reduced hydro-electricity, disrupted water transportation, and reduced raw water supply for domestic and urban industries.

e. Hydro topographic Drought; it has something to do with the change in river water levels during rainy and dry seasons and land topography.

2. Human Intervention

a. Drought resulting from human intervention occurs since the need for water is greater than the planned water supply as a result of user's non-compliance with cropping pattern or water use pattern.

b. Damaged water catchment area and water sources resulting from human intervention;

\section{Efforts in Managing Drought Disaster in Indonesia from the Context of Disaster Management Cycle}

Disaster risk management aims to avoid, mitigate, or divert harmful impacts from threats/hazards through prevention, mitigation and preparedness activities and efforts (D. A.P. Sari, Innaqa, \& Safrilah, 2017). Disaster management cycle consist of emergency response, recovery, mitigation and preparedness. Effort that has been done, planned and suggested at every steps of disaster management cycle in Indonesia are summarize as follows:

\section{Emergency Response}

Emergency response is the effort made immediately after the disaster occurs to deal with the negative impacts it creates, including rescue and evacuation activities of victims, properties, basic need fulfillment, protection, refugee handling, safety, and recovery of facilities and infrastructures. The emergency responses to drought disaster in Indonesia are;

1) Government fulfills people's needs for water and sanitation, food, health, and counseling.

2) Evacuation.

3) Treatment of emergency patients.

\section{Recovery from Disaster Event}

Yevjevich (Yevjevich, 1967) states that drought event influences social system, in addition to physical and environmental systems, thus drought management is a social responsibility, which is essentially directed towards the effort of supplying water and reducing/minimizing the impacts. Below are some discussions of the efforts of drought disaster response, of both non-physical and physical nature as well as long-term physical one. 


\section{a. Non-Physical Efforts}

Non-physical efforts are those attempts in the form of regulating, fostering and monitoring, such as:

1) Preparing regional water balance carefully.

2) Deciding on the sequence of water allocation priority.

3) Deciding on cropping pattern by considering water availability.

4) Preparing the pattern for irrigation facility operation.

5) Disseminating the "save water" movement and drought impacts.

6) Preparing food reserves/stock.

7) Preparing temporary job vacancies.

8) Monitoring and evaluating the implementation of drought treatment efforts.

\section{b. Emergency Physical Efforts}

The drought response efforts of emergency/temporary physical nature include:

1) Artificial rain seeding in rain catchment areas which have reservoirs, to enable the collection of water coming from the formed rain.

2) Making wells, to obtain water.

3) Provision of movable pumps in areas close to rivers or lakes, so that the pumps can be used in turn to obtain water.

4) Operation of drinking water provision using tank cars to supply water in dry and critical areas.

\section{c. Long-Term Physical Efforts}

The drought response efforts of long-term nature include:

1) Construction of irrigation infrastructures, such as reservoir, rubber dam (bendung karet), carrier channel, etc.

2) Implementation of water and water source conservation in rain catchment areas.

3) Highly efficient use of water.

4) Creation of water-efficient sanitation tools.

Mitigation Strategy and Disaster Reduction Efforts

1) Drafting of government regulations on arrangement of climate data delivery system from regions to data processing center

2) Drafting of Local Government Regulations to establish the water use priority scale in consideration of the historical rights and justice principles.

3) Establishment of working groups and posts at central and local levels.

4) Provision of special budget for development/repair of climate observation networks in drought-susceptible areas.

5) Development/Repair of climate observation networks in drought-susceptible areas.

6) Setting reward and punishment system for society who converse and rehabilitate water and forest/land resources.

\section{Drought Disaster Preparedness}

1) Utilizing existing sources of water more efficiently and effectively.

2) Prioritizing the utilization of available sources of water as raw water for clean water.

3) Planting as many plants and shrubs as possible in every inch of land existing in our residential environment.

4) Building on-farm reservoir according to the state of environment.

5) Adding more water infiltrations by not covering all surfaces with cement plaster or ceramic tiles.

6) "Save water" campaign, "save water" movement, protection of water sources.

7) Protection of their development water sources. 
8) Harvest and water conservation.

Water harvest is a method of collecting or gathering rainwater or flowing surface water when the rainfall is high for use during low rainfall. Water harvest should be followed by water conservation, i.e. using the harvested water in an efficient manner as needed. The construction of rorak (dead-end ditch) is an example of flowing surface water harvest and water conservation at the same time.

The areas in need of water harvest are those which have dry months (at a rainfall < $100 \mathrm{~mm}$ per month) for more than four months in a row and during rainy season its rainfall is really high (>200 $\mathrm{mm}$ per month). The excessive amount of water during rainy season is collected (harvested) for its use during dry season.

The water collection or 'water harvest' is useful to meet the water need of some plants, hence some parts of the land can still produce during dry season, or by changing the cropping pattern (Farobyfalatehan, Raswatie, \& Sari, 2017), local water harvest methods also reduces the erosion risk during rainy season. Those local methods are:

1) Rorak

Rorak is a small hole of $30-50 \mathrm{~cm}$ long/wide and $30-80 \mathrm{~cm}$ deep, used to collect some of the flowing surface water. The water coming into the rorak will inundate temporarily and slowly it will penetrate into the soil, leading to higher soil pore fulfillment by the water and reduced water surface flow. Rorakis suitable for areas with soil containing clay at high level where its infiltration is low - and the rainfall is high for a short time.

2) Dead-end channel

Dead-end channel is another form of rorak at a few meter long (thus it is called deadend channel). It is necessary to note that the construction of rorak or dead-end channel should never lead the water to inundate too long (for days) since it can disrupt the respiration of plant roots and develop many diseases to the roots.

3) Catch pit

The seeds freshly moved from polybag to the farmshould be prevented from experiencing any water deficiency. The 'catch pit' system takes the form of a small hole to collect water in order to maintain a high soil humidity inside the hole and around the plant root. The hole should be kept to prevent the water from inundating for days since it will result in the plant's death.

4) Embung (On-farm Reservoir)

Embung is an artificial pond to serve the function of collecting rainwater and surface water flow. It is recommended that the embung be constructed on a basin inside a micro watershed (DAS). During rainy season, the embung will be filled with flowing surface waterand water seepage inside the soil layer coming from the micro container at its upper/upstream part. The collected water can be used to water the plants, for domestic purposes, and for farm animals to drink during dry season.

The embung capacity ranges between $20,000 \mathrm{~m}^{3}(100 \mathrm{~m} \times 100 \mathrm{~m} \times 2 \mathrm{~m})$ and $60,000 \mathrm{~m} 3$. The large-sized embung is usually constructed using a bulldozer through village development project. Smaller-sized embung, at 200 to $500 \mathrm{~m} 3$ capacity, is also frequently found, yet it will only be capable of providing water to a very limited aread. Small embung can be constructed by the society independently.

Embung is suitable to be constructed in lands with relatively high content of clay so that the water infiltration would not be too great. In land with high water infiltration, such as sandy soil, most of the water will be gone unless the embungwall and bottom are layered with plastic or asphalt. However, it takes substantial amount of money to build. 


\section{5) Check Dam}

Check dam is the one at small rivers where the water flows only during rainy season, and during dry season it is dried. The water flow and sediment of these small rivers are collected inside the check dam, thus during the rainy seasonthe water level is higher and it makes the water distribution to the agricultural lands around them easier. During the dry season, it is expected that some amount of water is still remaining for the plants, livestock animal drinking, and many other purposes.

6) Rainwater harvest from house roof

The rainwater from house roof can be collected inside a tub or water tank for it to be utilized during dry season for washing, bathing, and watering the plants. For drinking water, it is recommended to use water from spring since in the beginning of rainy season, the rainwater contains dust at a high level.

\section{Conclusion.}

Based on the description above, efforts should be made to sustainably respond to drought, including:

1. People movement through counselling

In general, droughts happen in rural areas with its people lacking knowledge on how to manage water resources. The very existence of counselling will transfer the knowledge on how to optimize dried lands. One example of successful efforts is what has been done in Gunungkidul, Yogyakarta, where it used to be barren and has now had better ground water.

\section{Building/rehabilitating/maintaining irrigation networks}

Any irrigation network which is not maintained well will always be dry during dry season. The effort of building dam and reservoir is one of those efforts to collect river water during rainy season.

\section{Building wells}

Building well is something hard to do for people of low economic level. It is getting worse by the fact that they cannot build anything arbitrarily, since no sophisticated ground water detection tools is available so far. They are currently depending on water sources located so far away, which even prevent them from taking a bath regularly for water crisis reason.

\section{REFERENCES}

D'Arrigo, R., \& Smerdon, J. E. (2008). Tropical climate influences on drought variability over Java, Indonesia. Geophysical Research Letters, 35(5), 1-5. https://doi.org/10.1029/2007GL032589

Dandagi, S. R., Moreshwar, S. A., \& Raddi, S. A. (2013). A study to evaluate the effectiveness of planned teaching programme on knowledge regarding prevention of worm infestations among school children in selected government primary schools of Belgaum, Karnataka. Journal of Community Nutrition \& Health, 2(2), 11-19.

Deffi Ayu Puspito Sari. (n.d.). Food Production, Poverty Indices and Capability Related Variables (Case of Central Java and Yogyakarta Provinces). International Journal of Scientific Conference and Call for Papers. Retrieved from https://drive.google.com/file/d/1aZKI0jFTqX87ZREXaYGCVFpJXJAV3LTS/view

Farobyfalatehan, A., Raswatie, F. D., \& Sari, D. A. P. (2017). Planting and Consumption Patterns of Upland Rice Farmer in Indonesia, 1(1).

Field, R. D., van der Werf, G. R., \& Shen, S. S. P. (2009). Human amplification of droughtinduced biomass burning in Indonesia since 1960. Nature Geoscience, 2(3), 185-188. https://doi.org/10.1038/ngeo443 
Hualou, L. (2011). Disaster Prevention and Management : A Geographical Perspective. Disaster Advances, 4 No. 1(January 2011), 3-5.

Irawan, B. (2006). Fenomena Anomali Iklim El Nino Dan La Nina: Kecenderungan Jangka Panjang Dan Pengaruhnya Terhadap Produksi Pangan. Forum Penelitian Agro Ekonomi, 24(1), 28-45.

Lotfi, H., Nahavandian, M., \& Mohseninia, I. (2016). Climate Mitigation Strategies Drought Crisis in Iran. The 2016 WEI International Academic Conference Proceedings, 81-91.

MacEwen, L., Choudhuri, S., \& Bird, L. (2011). Education sector planning : working to mitigate the risk of violent conflict. Paper Commissioned for the EFA Global Monitoring Report.

Mamnunia, N., Sari, D. A. P., \& Heridadi, H. (2017). The Influence of Leadership and Competence in Puskesmas Preparedness for Supporting Flood Disaster Management (Case Study of Samarinda City in East Kalimantan Province, Indonesia). ADRI International Journal Of Environment and Disaster Management, 1(1), 18-26. Retrieved from http://ejournal.p-adri.org/index.php/ijedm/article/view/49

Nithya, A. R., Rahul, S., \& Sneha, N. S. (2016). A Conceptual Study on Logistics Planning for Emergency Supplies during Disaster. International Journal of Logistics \& Supply Chain Management Perspectives, 5(4), 2417-2582.

Puspitosari, D. A., \& Afriono, R. (2017). The Integration Of Cultural Resources Management In Disaster Management At Special Region Province Of Yogyakarta. Sinergi : Jurnal Ilmiah Ilmu Manajemen, 7(1). https://doi.org/10.25139/sng.v7i1.27

Sari, D. A. P. (2010). Changes in the Upland Crop Farm Economy in INDONESIA. TOHOKU JOURNAL OF RURAL ECONOMICS, 28(2), 30-37. https://doi.org/10.11617/jrset.28.2_30

Sari, D. A. P. (2012). Education, Health, and Basic Needs: Increasing Capabilities to Escape Poverty Human Insecurity. Journal of Human Security Research, 1(1). Retrieved from https://s3.amazonaws.com/academia.edu.documents/32003241/JOHSS_vol.1_2011w.pdf ?AWSAccessKeyId=AKIAIWOWYYGZ2Y53UL3A\&Expires $=1515810207 \&$ Signature $=\mathrm{m} 5$ UFYP\%2F3X5BmDxgAA\%2FE5IVskjqU\%3D\&response-content-disposition=inline\%3B filename\%3DPeacebuilding_and_Security

Sari, D. A. P., Innaqa, S., \& Safrilah. (2017). Hazard, Vulnerability and Capacity Mapping for Landslides Risk Analysis using Geographic Information System (GIS). In IOP Conference Series: Materials Science and Engineering. https://doi.org/10.1088/1757-899X/209/1/012106

Sari, D. A. P., \& Kawashima, S. (2016). Poverty Mapping And Poverty Analysis In Indonesia. Jurnal Agro Ekonomi, 28(1), 95. https://doi.org/10.21082/jae.v28n1.2010.95-111

Tamim Syaifullah, M., \& Manzilati, A. (2015). Analisis Pemenuhan Kebutuhan dan Penyelesaian Kelangkaan Sumber Daya Air (Studi Kasus Kelurahan Tlogowaru, Malang). JIEP, 15(1), 27-49. Retrieved from https://media.neliti.com/media/publications/182740-ID-analisis-pemenuhan-kebutuhandan-penyele_I3buBHP.pdf

Toggweiler, J. R., \& Key, R. M. (2003). OCEAN CIRCULATION I Thermohaline Circulation. Encyclopedia of Atmospheric Sciences, 1549-1555. https://doi.org/10.1016/B0-12-2270908/00281-5

Wand, M. Z., Ayuba, I. G. U., \& Asika, B. G. (2015). Needs for Disaster Risks Reduction Education in Nigeria. IOSR Journal of Environmental Science, Toxicology and Food Technology, 9(1), 43-47. https://doi.org/10.9790/2402-09134347

Yevjevich, V. (1967). An objective approach to definitions and investigations of continental hydrologic droughts. Hydrology Papers 23, (23), 25. https://doi.org/10.1016/00221694(69)90110-3 